\title{
ANALISIS POLA PERJALANAN DAN AKTIVITAS WISATAWAN INDONESIA MILENIAL KE SINGAPURA
}

\author{
Kiki Savira ${ }^{1}$, I Ketut Suwena ${ }^{2}$, I Putu Sudana ${ }^{3}$ \\ Email: kikisavira98@gmail.com ${ }^{1}$, suwenaketut31@gmail.com², sudanaputu@yahoo.com ${ }^{3}$ \\ ${ }^{1,2,3}$ Program Studi Industri Perjalanan Wisata, Fakultas Pariwisata, Universitas Udayana
}

\begin{abstract}
Millennial recently became a trend in tourism. Millennials were born in 1980 to 2004, they grew up as digital natives, and have a consumptive nature where they do not hesitate to spend a certain amount of money to please themselves such as traveling, both at home and abroad. One of the countries that is a favorite destination for millennial Indonesian tourists when traveling abroad is Singapore. In addition to its close location, Singapore also has modern urban tourism attractions and technologies that match the millennial character. These facts became the background of this research; characteristics, travel patterns, and activities of millennial Indonesian tourists while traveling in Singapore. This research uses descriptive qualitative data analysis. The sample was determined purposively, totaling 105 millennial tourists from Indonesia who had traveled to Singapore. The data collection technique was done by using an online questionnaire. The results showed that the characteristics of millennial Indonesian tourists in Singapore were female, aged 21 to 25 years, unmarried, had a Bachelor's degree and were a private employee. Most tourists are first time traveling to Singapore, stay in Singapore 3 to 7 days, come and travel with family, arranging their own trips, using the internet as a source of information and mostly using MRT (Mass Rapid Transit) as a mode of transportation while traveling in Singapore. There are two millennial Indonesian tourists' travel patterns while traveling in Singapore, which are chaining loop pattern, and base site pattern. The most common millennial Indonesian tourists' activities in Singapore is doing culinary tourism (75\%), the second is shopping (66\%), and the third is enjoying local cultures $(51 \%)$.
\end{abstract}

Abstrak: Generasi milenial saat ini menjadi sebuah tren yang hangat di bidang pariwisata. Ciri-ciri generasi milenial ialah lahir di tahun 1980-an hingga tahun 2004, tumbuh bersama kemajuan teknologi, dan memiliki sifat konsumtif, tidak segan mengeluarkan sejumlah uang untuk menyenangkan diri sendiri seperti berwisata, baik di dalam maupun di luar negeri. Salah satu negara favorit wisatawan Indonesia milenial saat berwisata ke luar negeri adalah Negara Singapura. Lokasinya yang dekat serta teknologi yang maju, dan daya tarik wisata perkotaan modern Singapura sesuai dengan karakter generasi milenial. Fakta-fakta tersebut melatarbelakangi penelitian karakteristik, pola perjalanan, serta aktivitas wisatawan Indonesia milenial selama berwisata di Singapura. Penelitian ini menggunakan analisis deskriptif kualitatif. Sampel ditentukan secara purposive berjumlah 105 wisatawan milenial asal Indonesia yang pernah berwisata ke Singapura. Teknik pengumpulan data dilakukan dengan kuesioner secara online. Hasil penelitian menunjukkan bahwa karakteristik wisatawan Indonesia milenial yang berwisata ke Singapura adalah berjenis kelamin wanita, berusia 21 hingga 25 tahun, belum menikah, tingkat pendidikannya Sarjana dan berprofesi sebagai pegawai swasta. Mayoritas wisatawan baru pertama kali berwisata ke Singapura (first timer), tinggal selama 3 hingga 7 hari, datang dan melakukan perjalanan bersama keluarga, mengatur sendiri perjalanannya, menggunakan fasilitas internet sebagai sumber informasi dan menggunakan MRT (Mass Rapid Transit) sebagai moda transportasi berwisata di Singapura. Terdapat dua pola perjalanan wisatawan Indonesia milenial ketika berwisata ke Singapura, yaitu base site (dua destinasi, dan tiga destinasi), dan chaining loop. Aktivitas wisatawan $75 \%$ adalah wisata kuliner, $66 \%$ berbelanja, dan $51 \%$ menikmati budaya lokal.

Keywords: characteristics, travel pattern, tourist activities, indonesian millennial tourists, singapore. 


\section{PENDAHULUAN}

Pariwisata menjadi salah satu kebutuhan esensial manusia di luar kebutuhan pokok lainnya. Dewa Gde Satrya mengatakan bahwa kebutuhan manusia akan kegiatan wisata dalam rangka menyeimbangkan kehidupan (live balancing) dari rutinitas manusia sehari-hari. Di tengah tingkat mobilitas yang tinggi pada era modern, mengunjungi tempat-tempat baru terutama mengadakan perjalanan ke luar negeri mampu memberikan energi positif, menambah wawasan dan pengalaman serta menghilangkan rasa jenuh dari aktivitas sehari-hari. Berdasarkan survei online travel agent Traveloka dan konsultan pariwisata spesialis outbound tourism Pear Anderson, salah satu negara favorit wisatawan Indonesia saat melakukan perjalanan ke luar negeri ialah Singapura.

Hubungan Bilateral Indonesia dan Singapura dalam bidang pariwisata telah terjalin sejak lama. Pasar Indonesia adalah salah satu pasar terpenting bagi pariwisata Singapura dan pada tahun 2019, kunjungan wisatawan Indonesia merupakan kedua terbanyak setelah Tiongkok dengan jumlah 3.109.000 wisatawan. Kenneth Lim (Regional Director of ASEAN and Oceania, Singapore Tourism Board dalam Kompas.com) mengatakan Singapura menjadi destinasi gaya hidup bagi sebagian besar masyarakat Indonesia. Alasan terkuatnya adalah banyaknya penerbangan LCC (Low Cost Carrier) dari Indonesia ke Singapura. Jumlah penerbangan yang banyak turut memudahkan wisatawan Indonesia mengadakan perjalanan wisata ke Singapura.

Adanya efek entertainment seperti diselenggarakannya konser-konser musisi ternama di Singapura turut menjadi alasan wisatawan Indonesia berkunjung ke Singapura, terutama bagi wisatawan Indonesia yang tergolong generasi milenial (Gen Y). Selain itu, Singapura merupakan negara dengan lingkungan teknologi terbaik peringkat enam di dunia, dan nomor satu di Asia (dalam Getzoff, 2020). Keterkaitan kuat antara teknologi dengan wisatawan milenial menjadi nilai tambah bagi negara Singapura.

Neil Howe dan William Strauss (dalam Pratama, 2019) menyatakan generasi milenial adalah generasi yang lahir dalam kisaran tahun 1980-an hingga 2004, dengan kisaran umur 17 tahun hingga 39 tahun. Menurut pernyataan sebuah media online Travel Kompas (dalam Leli Kusuma Dewi, 2020), wisatawan milenial memiliki caranya sendiri saat melakukan perjalanan wisata. Wisatawan milenial cenderung mengadakan perjalanan wisata secara spontan, dan tidak membutuhkan waktu banyak untuk perencanaan. Wisatawan dengan latar belakang generasi milenial saat ini berpotensi paling besar dalam arus pariwisata karena usia yang tergolong produktif dan populasi yang amat banyak di dunia (dalam Leli Kusuma Dewi, 2020). Wisatawan milenial memainkan peranan penting dalam pariwisata dan citra destinasi. Wisatawan milenial dianggap sebagai 'penghasut' tren perjalanan, dimana sebagian besar dari wisatawan milenial adalah pelancong perintis yang menemukan dan mempromosikan destinasi yang belum dikunjungi oleh wisatawan generasi lainnya.

Ketika wisatawan melakukan perjalanan, maka akan terbentuk sebuah pola pergerakan dari perjalanan wisatanya. Pola perjalanan wisatawan adalah keterkaitan mata rantai perjalanan dari tempat wisatawan tinggal selama di destinasi tersebut $(h u b)$, melalui sebuah pintu masuk/keluar menuju sebuah destinasi (entry point) yang didalamnya terdapat fasilitas yang digunakan oleh wisatawan tersebut untuk menunjang kegiatan kepariwisataan hingga atraksi wisata, apa yang akan dilakukan, dilihat dan dibeli oleh wisatawan di sekitar daya tarik wisata tersebut (Pratama, 2020).

Pola perjalanan wisatawan berkaitan erat dengan aktivitas wisatawan saat berada di destinasi wisata. Aktivitas wisata terbagi menjadi tiga jenis yaitu aktivitas alam, aktivitas budaya, dan aktivitas minat khusus. Aktivitas wisatawan mempengaruhi lama perjalanan wisatawan dan mencerminkan minat wisatawan Indonesia milenial apabila berwisata di daerah perkotaan seperti Singapura. Dengan dilakukannya penelitian mengenai pola perjalanan (travel pattern) dan aktivitas wisatawan (tourist activities) maka dapat membuahkan informasi detil perihal perjalanan wisatawan Indonesia milenial yang berwisata ke Singapura yang bermanfaat bagi para pelaku pariwisata dan akademisi. Hasil penelitian ini diharapkan dapat membantu mengenali pola wisata masyarakat Indonesia milenial, mengurangi keluhan, dan membangun sisi pariwisata perkotaan Indonesia dengan Singapura. Para akademisi, penelitian ini 
diharapkan dapat menjadi acuan dan sumber informasi untuk penelitian selanjutnya.

\section{METODE}

Variabel yang diteliti dalam penelitian ini ada tiga, yaitu karakteristik wisatawan, pola perjalanan wisatawan, dan aktivitas wisatawan. Variabel karakteristik wisatawan menggunakan teori Seaton dan Bennett (dalam Suwena dan Widyatmaja, 2017) yang terdiri atas 2 subvariabel, yaitu Tourist Descriptor (karakteristik data pribadi wisatawan) dan Trip Descriptor (karakteristik mengenai perjalanan wisatawan). Tourist Descriptor berisi 7 butir indikator, antara lain: Nama, Jenis Kelamin, Usia, Tingkat Pendidikan, Pekerjaan, Daerah Asal, dan Status Pernikahan. Trip Descriptor berisi 7 butir indikator, yakni: Frekuensi Kunjungan, Lama Waktu Perjalanan, Teman Perjalanan, Pengorganisasian Perjalanan, Sumber Informasi, Akomodasi Wisata, dan Moda Transportasi.

Variabel pola perjalanan berisi tiga jenis pola, yaitu Single Pattern, Multiple Pattern, dan Complex Pattern. Single Pattern (Single Point) adalah pola dimana wisatawan hanya mengunjungi satu destinasi, kemudian kembali ke tempat wisatawan tersebut tinggal. Multiple Pattern adalah pola dimana wisatawan mengunjungi lebih dari satu destinasi. Terdapat tiga pola perjalanan yang tergolong dalam Multiple Pattern, yaitu: Base Site adalah saat wisatawan mengunjungi destinasi utama kemudian menyebar mengunjungi destinasi tujuan sekunder lainnya; Stopover adalah saat wisatawan mengunjungi destinasi tujuan sekundernya terlebih dahulu, kemudian mengunjungi destinasi utama di akhir perjalanan; dan Chaining Loop adalah saat dimana wisatawan melakukan rute memutar yang berarti mengunjungi lebih dari satu destinasi tanpa melakukan pengulangan rute. Pola perjalanan terakhir adalah Complex Pattern, yaitu pola gabungan antara satu pola perjalanan dengan yang lainnya (Lew dan McKercher dalam Utami, 2019).

Variabel Aktivitas Wisatawan berisi tiga jenis kegiatan, yaitu aktivitas wisata alam, aktivitas wisata budaya, dan aktivitas wisata minat khusus. Pada penelitian ini, indikator aktivitas wisata alam bagi wisatawan Indonesia milenial yang mengunjungi Singapura ada dua, yaitu mengunjungi taman dan/atau pantai, dan mengunjungi kebun binatang. Indikator aktivitas wisata budaya terdapat tiga subindikator, yaitu melakukan wisata kuliner, berwisata ke museum dan/atau galeri, dan menikmati budaya lokal dengan mengunjungi landmark budaya (Bugis Street, Little India, dan Chinatown). Indikator aktivitas wisata minat khusus berisi empat sub-indikator, antara lain: melakukan wisata belanja, bermain kasino, mengunjungi taman hiburan (amusement park), dan melakukan wisata medis.

Teknik pengumpulan data dalam penelitian ini hanya menggunakan kuesioner dan studi kepustakaan dikarenakan penelitian terjadi Covid-19. Penelitian ini menggunakan kuesioner daring (online) menggunakan media Google Form untuk disebarluaskan melalui media sosial. Media sosial yang digunakan dalam penyebaran kuesioner penelitian ini adalah Whatsapp dan Instagram.

Teknik penentuan sampel dilakukan dengan cara purposive sampling, yaitu peneliti mencari responden yang berusia 17 hingga 19 tahun dan pernah melakukan perjalanan ke Singapura. Penentuan jumlah sampel menggunakan rumus Jumlah Indikator dikalikan 5 sampai 10. Dalam kuesioner penelitian ini terdapat 21 indikator, jika dikalikan 5 akan mendapatkan hasil 105. Oleh karena itu, jumlah responden dalam penelitian ini berjumlah 105 wisatawan Indonesia milenial.

Teknik analisis data yang digunakan dalam penelitian ini adalah deskriptif kualitatif. Metode deskriptif kualitatif adalah metode penelitian yang membuat gambaran mengenai situasi atau kejadian, sehingga metode ini berkehendak mengadakan akumulasi data dasar berskala (Nazir dalam Pratama, 2020). Metode ini digunakan untuk mendeskripsikan dan menjabarkan pola perjalanan dan aktiviats wisatawan Indonesia milenial yang pernah berwisata ke Singapura.

\section{HASIL DAN PEMBAHASAN}

Singapura merupakan satu-satunya negara maju yang terletak di wilayah Asia Tenggara. Singapura memiliki luas wilayah $725,7 \mathrm{~km}^{2}$, dengan letak astronomis $103,5^{\circ} \mathrm{LU}$ hingga $104,4^{\circ} \mathrm{LU}$ dan $1^{\circ} \mathrm{BT}$ hingga $1,5^{\circ} \mathrm{BT}$. Singapura berbatasan dengan Selat Johor di Utara, Selat Karimata di bagian Timur, Selat Singapura pada bagian Selatan, dan Selat Malaka di Barat (dalam Hidayat, 2018). 
Singapura adalah salah satu negara favorit wisatawan Indonesia milenial (Indonesia Outbound Travel Profile, 2019). Singapura terkenal akan wisata perkotaan dan wisata minat khususnya. Aktivitas yang biasanya dilakukan oleh wisatawan di Singapura adalah berbelanja, mengunjungi Universal Studio di Pulau Sentosa, berkeliling sekitar kota, dan menikmati hidangan khas Singapura (Visit Singapore, 2019). Singapura memiliki banyak daya tarik dan destinasi wisata unggulan yang sering dikunjungi oleh wisatawan Indonesia.

Pada penelitian ini, peneliti memilih 9 destinasi wisata, antara lain Marina Bay Singapore, Sentosa Island, Singapore Zoo, Orchard Road, Gardens By The Bay, Singapore River, Bugis Street, Little India, dan Chinatown. Destinasi-destinasi tersebut merupakan destinasi wisata yang kerap tertulis di media mengenai destinasi favorit wisatawan Indonesia di Singapura. Singapore Zoo, Singapore River, dan Gardens By The Bay termasuk dalam kategori daya tarik wisata alam. Marina Bay Singapore, Sentosa Island, dan Orchard Road termasuk dalam daya tarik wisata buatan. Bugis Street, Little India, dan Chinatown termasuk dalam daya tarik wisata budaya.

\section{Karakteristik Wisatawan}

Berdasarkan hasil penelitian, berikut adalah karakteristik wisatawan Indonesia milenial yang pernah berwisata ke Singapura.

1. Mayoritas responden yang pernah berwisata ke Singapura berjenis kelamin Perempuan, dengan jumlah 59 (56.2\%) dari 105 wisatawan. Singapura merupakan salah satu dari 10 negara teraman di dunia (Global Index by Vision of Humanity, 2020). Tingkat kriminalitas yang rendah memberikan rasa aman dan nyaman ketika berwisata. Hal ini diduga merupakan penyebab dominasi wisatawan Indonesia milenial berjenis kelamin perempuan lebih suka ke Singapura.

2. Mayoritas responden berusia 21 hingga 25 tahun, dengan jumlah 66 (62.9\%) dari 105 wisatawan. Pada rentang usia ini biasanya manusia memasuki usia produktif yang dimana sudah dapat menghasilkan pendapatan sendiri. Hal ini merupakan salah satu alasan mengapa lebih banyak wisatawan dengan usia 21 hingga 25 tahun yang berwisata ke Singapura dibandingkan dengan rentang umur lainnya.

3. Mayoritas responden telah atau sedang menempuh pendidikan Sarjana (Strata 1), dengan jumlah 66 (62.9\%) dari 105 wisatawan. Wisatawan Indonesia milenial memiliki tingkat pendidikan SMA menempati peringkat kedua dengan jumlah $26(24.8 \%)$ responden, diikuti oleh wisatawan dengan tingkat pendidikan Magister (Strata 2) sejumlah 7 (6.7) responden, dan wisatawan dengan tingkat pendidikan Diploma sejumlah 6 (5.7\%) responden.

4. Mayoritas responden merupakan Pegawai Swasta dengan jumlah 31 (29.5\%) dari 105 wisatawan. Wisatawan yang berstatus pegawai swasta telah mandiri secara finansial sehingga mereka dapat mengalokasikan pendapatannya untuk halhal yang bersifat menyenangkan diri sendiri seperti berwisata. Kegiatan wisata dapat dilakukan oleh para pegawai swasta apabila mereka mendapatkan waktu luang pada hari cuti atau hari libur.

5. Mayoritas responden berasal dari Kota Tangerang (28 (26.7\%) responden), DKI Jakarta (14 (13.3\%) responden), dan Kota Denpasar (13 (12.4\%) responden). Wisatawan-wisatawan tersebut memiliki satu kesamaan yaitu berasal dari daerah perkotaan yang padat penduduk. Masyarakat daerah perkotaan biasanya memiliki intensitas bekerja yang tingga sehingga ketika mereka mendapatkan waktu luang seperti hari libur, mereka cenderung ingin menghabiskan waktu luang yang bernilai seperti berwisata.

6. Mayoritas responden berstatus Belum Menikah, dengan jumlah 92 (87.6\%) dari 105 wisatawan. Responden yang belum menikah biasanya memiliki waktu luang yang lebih banyak dibandingkan dengan yang sudah menikah. Wisatawan yang belum menikah rata-rata juga belum memiliki tanggungan wajib seperti yang sudah menikah. Kedua faktor ini dapat menjadi alasan banyak wisatawan Indonesia milenial dengan status belum menikah memutuskan berwisata ke Singapura.

7. Mayoritas responden mengunjungi Singapura untuk pertama kalinya (wisatawan first-timer), dengan jumlah 50 
(47.6\%) dari 105 wisatawan. Wisatawan Indonesia milenial yang telah mengunjungi Singapura dua sampai tiga kali berjumlah $31(29.5 \%)$ dari 105 responden, sedangkan wisatawan Indonesia milenial yang telah mengunjungi lebih dari tiga kali berjumlah $24(22.9 \%)$ dari 105 responden

8. Mayoritas responden berwisata di Singapura selama 3 sampai 7 hari berjumlah 59 (56.2\%) dar 105 wisatawan. Hal ini dapat disebabkan oleh banyaknya responden yang berstatus pelajar dan pegawai swasta, yang mana respondenresponden tersebut masih memiliki tanggung jawab terkait pekerjaannya dan memiliki waktu yang terbatas untuk berwisata. Wilayah Singapura yang tidak luas, daya tarik wisata yang letaknya berdekatan, serta besar biaya yang dikeluarkan untuk perjalanan menjadi alasan tambahan mengapa wisatawan Indonesia milenial kebanyakan memilih berwisata selama $\leq 7$ hari.

9. Mayoritas responden berwisata bersama dengan keluarga, dengan jumlah 44 (41.9\%) dari 105 wisatawan. Banyaknya daya tarik wisata di Singapura yang cocok untuk berwisata dengan keluarga, seperti Universal Studios, Marina Bay Singapore, Singapore Zoo, Chinatown, Orchard Road, dan lainnya menjadi alasan mengapa banyak wisatawan Indonesia milenial yang berwisata dengan keluarga.

10. Mayoritas responden mengatur perjalanannya sendiri (self-organized) dengan jumlah 91 (86.7\%) dari 105 wisatawan. Hasil ini membuktikan bahwa wisatawan Indonesia milenial menyukai perjalanan wisata yang lebih fleksibel dan wisatawan tidak terikat pada jadwal dalam paket wisata dari Biro Perjalanan Wisata. Wisatawan Indonesia milenial yang berwisata ke Singapura rata-rata menempuh pendidikan yang tinggi menimbulkan fakta bahwa wisatawan Indonesia milenial cukup mandiri dalam membuat keputusan-keputusan perjalanan wisatanya. Kemudahan menggunakan teknologi bagi wisatawan milenial serta negara Singapura yang terbukti ramah teknologi merupakan alasan mengapa wisatawan Indonesia milenial mengatur perjalanannya sendiri.
11. Wisatawan Indonesia milenial mayoritas mendapatkan informasi mengenai hal-hal yang diperlukan dalam perjalanan wisatanya ke Singapura dari Internet, dengan jumlah 61 (58.1\%) dari 105 responden. Data ini sesuai dengan karakter generasi milenial yang tumbuh dan berkembang seiring dengan perkembangan teknologi sehingga bisa memanfaatkan keberadaan teknologi untuk memudahkan saat melakukan kegiatan wisata. Mesin pencarian di Internet memiliki sangat banyak informasi terkait hal-hal tentang Singapura, baik situs resmi dari Pemerintah Singapura maupun blog atau catatan pribadi milik para wisatawan. Semuanya memberikan informasi secara gratis kepada wisatawan milenial melalui Internet.

12. Jenis akomodasi yang paling banyak digunakan oleh wisatawan Indonesia milenial selama berwisata di Singapura adalah Hotel, dengan jumlah 62 (59\%) dari 105 wisatawan. Singapura memiliki 410 hotel pada tahun 2018, dan hotel-hotel tersebut dapat direservasi secara daring (online) melalui perusahaan yang melayani layanan pemesanan akomodasi seperti Traveloka, Agoda, Pegipegi, Airbnb, dan lainnya. Kemudahan reservasi secara daring membuat wisatawan milenial lebih memilih untuk menginap di Hotel dibandingkan dengan akomodasi lainnya.

13. Selama berwisata di Singapura, wisatawan Indonesia milenial menggunakan lebih dari satu moda transportasi. Tiga moda transportasi yang paling banyak digunakan adalah menggunakan Kereta MRT (87 $(82.9 \%)$ dari 105 wisatawan), berjalan kaki (77 (73.3\%) dari 105 wisatawan), dan menggunakan Bus (70 (66.7\%) dari 105 wisatawan). Kereta MRT merupakan moda transportasi umum tercepat di Singapura. Oleh karena itu, wisatawan Indonesia milenial banyak yang memilih menggunakan MRT. Selain menggunakan MRT, wisatawan juga berjalan kaki dan menggunakan Bus layaknya masyarakat lokal Singapura. Keberadaan transportasi umum di Singapura sangat dihargai oleh masyarakat lokal Singapura sehingga mereka terbiasa untuk menggunakan transportasi umum. Kebisaan ini 
kemudian dijadikan cerminan bagi wisatawan yang berkunjung ke Singapura.

\section{Pola Perjalanan Wisatawan}

Sebelum memasuki bahasan mengenai pola perjalanan wisatawan, peneliti perlu menyampaikan membahas mengenai urutan destinasi wisata favorit wisatawan Indonesia milenial di Singapura pada tabel berikut ini.

Tabel 1. Urutan Destinasi Favorit Wisatawan Indonesia Milenial di Singapura

\begin{tabular}{clcc}
\hline No & $\begin{array}{l}\text { Destinasi } \\
\text { Wisata }\end{array}$ & $\begin{array}{c}\text { Jumlah } \\
\text { Wisatawan }\end{array}$ & Persentase \\
\hline 1 & $\begin{array}{l}\text { Marina Bay } \\
\text { Singapore }\end{array}$ & 88 & $83.8 \%$ \\
\hline 2 & $\begin{array}{l}\text { Sentosa } \\
\text { Island }\end{array}$ & 71 & $67.6 \%$ \\
\hline 3 & Chinatown & 69 & $65.7 \%$ \\
\hline 4 & $\begin{array}{l}\text { Orchard } \\
\text { Road }\end{array}$ & 67 & $63.8 \%$ \\
\hline 5 & $\begin{array}{l}\text { Gardens By } \\
\text { the Bay }\end{array}$ & 65 & $61.9 \%$ \\
\hline 6 & Bugis Street & 49 & $46.7 \%$ \\
\hline 7 & Little India & 37 & $35.2 \%$ \\
\hline 8 & $\begin{array}{l}\text { Singapore } \\
\text { River }\end{array}$ & 34 & $32.3 \%$ \\
\hline 9 & $\begin{array}{l}\text { Singapore } \\
\text { Zoo }\end{array}$ & 32 & $30.4 \%$ \\
\hline
\end{tabular}

Sumber: Hasil penelitian, 2020.

Berdasarkan Tabel 1, kebanyakan destinasi dengan posisi teratas merupakan destinasi wisata minat khusus, seperti Marina Bay Singapore dan Sentosa Island. Hal ini menunjukkan bahwa tipologi wisatawan Indonesia milenial menurut teori tipologi Cohen (dalam Pratama, 2020) ketika berwisata ke Singapura adalah diversionary dan recreational. Diversionary berarti wisatawan mencari pelarian dari rutinitas kehidupan sehari-hari, dan recreational berarti wsatawan melakukan perjalanan untuk menghibur diri sehingga mereka tidak mementingkan faktor keaslian (authenticity) dari destinasi wisata. Jika dikaitkan dengan teori tipologi Plog (dalam Pratama, 2020), maka wisatawan Indonesia milenial termasuk dalam kategori psychocentric, yaitu wisatawan Indonesia milenial mencari destinasi wisata perkotaan Kota Singapura yang telah terkenal dan memiliki karakter dan fasilitas yang serupa dengan destinasi wisata perkotaan di Indonesia.
Wisatawan Indonesia milenial terlihat tidak tertarik dengan destinasi wisata alam yang ada di Singapura.

Menurut teori Lew dan McKercher (dalam Utami, 2019) terdapat enam jenis pola perjalanan wisatawan, antara lain: single point, base site, stopover, chaining loop, destination region loop, dan complex neighbourhood. Pada hasil penelitian ini hanya ditemukan dua jenis pola perjalanan yang terjadi pada wisatawan Indonesia milenial di Singapura. Pola perjalanan pertama adalah base site yang terbagi menjadi dua yaitu base site dua destinasi, dan base site tiga destinasi.

Pola Perjalanan Base Site Dua Destinasi adalah pola dimana wisatawan hanya mengunjungi dua destinasi, yaitu destinasi utama, kemudian melakukan perjalanan ke satu destinasi selanjutnya. Hasil dari penelitian ini menunjukkan bahwa wisatawan Indonesia milenial memilih Marina Bay Singapore sebagai destinasi utama, dan Orchard Road sebagai destinasi selanjutnya. Berdasarkan hasil penelitian pada Tabel 1, terlihat bahwa wisatawan Indonesia milenial memiliki minat yang tinggi untuk mengunjungi Marina Bay Singapore, dan dapat disimpulkan bahwa kawasan ini merupakan destinasi yang wajib dikunjungi apabila wisatawan Indonesia hendak berwisata ke Singapura.

Setelah berwisata di Kawasan Marina Bay Singapore, wisatawan Indonesia milenial memilih melanjutkan perjalanan menuju Orchard Road. Orchard Road merupakan kawasan pusat perbelanjaan di Singapura yang paling terkenal bagi wisatawan asing yang berkunjung ke Singapura. Orchard Road menjadi kawasan pusat kota yang ramai dengan hiruk-pikuk perkotaan yang khas. Destinasi ini menawarkan pengalaman berwisata seperti masyarakat lokal, dimana wisatawan dapat melakukan aktivitas seperti pergi ke bioskop, berbelanja di mal, atau hanya berjalan-jalan menikmati suasana pusat Kota Singapura pada malam hari.

Pola perjalanan selanjutnya adalah Base Site Tiga Destinasi, dimana wisatawan mengunjungi tiga destinasi, yaitu destinasi utama, dan dua destinasi lainnya. Wisatawan Indonesia milenial dengan pola perjalanan ini memilih Sentosa Island sebagai destinasi utamanya, kemudian melanjutkan perjalanan menuju Gardens By The Bay, dan mengunjungi Orchard Road sebagai destinasi akhir. 
Pulau Sentosa merupakan kawasan wisata dengan berbagai macam atraksi wisata yang terkenal di dunia, seperti Universal Studios Singapore, Madame Tussauds Singapore, Akuarium S.E.A, Sentosa Merlion, dan lainlain. Wisatawan dapat menaiki berbagai macam wahana permainan yang menyenangkan di Taman Bermain Universal Studios, dan juga wahana yang berupa transportasi seperti gondola (cable car); kemudian terdapat juga kendaraan roda tiga yang dikemudikan dengan gravitasi, yaitu The Skyline Luge; dan kursi gantung seperti ayunan besar untuk melihat pemandangan Singapura dari ketinggian, yaitu Skyride. Setelah wisatawan menggunakan waktunya untuk berwisata di Pulau Sentosa, wisatawan menuju Gardens By The Bay. Gardens By The Bay merupakan sebuah destinasi wisata berupa taman buatan yang memiliki ragam jenis hortikultura dan desain arsitektur taman yang indah, perpaduan antara wisata buatan dan wisata alam. Gardens By The Bay terletak di Wilayah Teluk Marina berdampingan dengan Hotel Marina Bay Singapore. Gardens By The Bay sangat cocok menjadi destinasi wisata bagi wisatawan milenial yang bepergian dengan keluarga karena dapat dinikmati oleh berbagai kalangan dan usia. Setelah berkunjung ke Gardens By The Bay, wisatawan Indonesia milenial memilih Orchard Road sebagai tempat berkunjung selanjutnya.

Orchard Road terkenal sebagai tempat untuk melakukan wisata belanja terbesar di Singapura. Sebelum pulang ke Indonesia, wisatawan Indonesia milenial dapat berbelanja terlebih dahulu di kawasan ini. Berbelanja merupakan kegiatan yang cukup menyita waktu. Oleh karena itu sangatlah wajar apabila Orchard Road dipilih sebagai destinasi terakhir dari perjalanan wisata. Selain berbelanja, wisatawan Indonesia milenial dapat melakukan aktivitas lainnya seperti bersantai di sepanjang jalan Orchard, menikmati kudapan kaki lima Uncle Ice Cream seperti layaknya masyarakat lokal, dan melakukan swafoto dengan gedunggedung di Orchard Road. Kawasan Orchard Road juga memiliki pameran ornamenornamen Hari Raya yang bercahaya indah ketika malam hari sehingga mengunjungi Orchard Road di penghujung hari merupakan keputusan yang tepat bagi wisatawan Indonesia milenial.
Kedua, pola perjalanan chaining loop. Pola ini paling banyak dilaksanakan oleh wisatawan Indonesia milenial, dengan jumlah destinasi yang dikunjungi adalah lima destinasi. Wisatawan Indonesia milenial dengan pola perjalanan ini memilih Marina Bay Singapore sebagai destinasi utama, kemudian melanjutkan perjalanan menuju Chinatown, Orchard Road, Gardens By The Bay, dan destinasi terakhir adalah Sentosa Island. Pada penelitian ini dapat disimpulkan bahwa Marina Bay Singapore merupakan destinasi wisata utama dan merupakan detinasi yang paling terkenal bagi wisatawan Indonesia milenial. Selanjutnya, wisatawan mengunjungi destinasi kedua yaitu Chinatown. Mayoritas penduduk di Singapura adalah etnis Tionghoa. Oleh karena itu, Chinatown menjadi destinasi wisata budaya yang paling terkenal di Singapura karena Chinatown menjadi wajah dari pariwisata budaya Singapura. Setelah mengunjungi Chinatown, wisatawan melakukan perjalanan menuju Orchard Road. Kawasan Orchard Road Singapura merupakan kawasan pusat kota yang dikenal cocok untuk bersantai, berbelanja, dan berswafoto (selfie) dengan latar belakamg gedung-gedung berdesain modern dan futuristic.

Setelah berwisata ke tiga destinasi wisata perkotaan, wisatawan memilih untuk berwisata ke destinasi wisata alam yaitu Gardens By The Bay. Wisatawan dapat berjalan menyusuri taman dan mendapatkan ilmu pengetahuan mengenai dunia hortikultura. Gardens By The Bay adalah destinasi wisata yang cocok bagi seluruh tingkatan usia. Destinasi terakhir yang dituju oleh wisatawan adalah Sentosa Island. Wisatawan dapat menghabiskan sisa waktu liburannya dengan mengelilingi Pulau Sentosa, menikmati ragam aktivitas wisata yang terdapat di pulau tersebut.

Berdasarkan hasil penelitian yang telah dilakukan, wisatawan Indonesia milenial yang berwisata ke Singapura memiliki ciri khusus, yakni memilih untuk mengunjungi tempattempat yang telah terkenal seperti Marina Bay dan Orchard Road. Wisatawan Indonesia lebih memilih untuk berjalan-jalan di sekitar Kota Singapura, menikmati nuansa wisata perkotaan (city tour), dan menemukan lokasi-lokasi tepat untuk melakukan swafoto (selfie). Hasil penelitian ini sejajar dengan pernyataan Kenneth Lim (hal 2.) bahwa Singapura 
merupakan destinasi gaya hidup bagi masyarakat Indonesia.

\section{Aktivitas Wisatawan}

Variabel Aktivitas Wisatawan pada penelitian ini terbagi menjadi tiga sub-variabel, yaitu aktivitas wisata alam, aktivitas wisata budaya, dan aktivitas wisata buatan. Berikut adalah tabel hasil penelitian mengenai aktivitas wisatawan Indonesia milenial selama melakukan perjalanan wisata di Singapura. Berdasarkan hasil penelitian, ada tiga aktivitas wisata yang paling banyak dilakukan oleh wisatawan Indonesia milenial, yaitu wisata kuliner, wisata belanja, dan wisata budaya (menikmati budaya lokal). Perpaduan budaya yang terdapat di negara Singapura membuat Singapura memiliki ragam jenis makanan khas yang wajib dinikmati oleh wisatawan ketika berkunjung ke Singapura. Budaya Tiongkok membuahkan makanan khas yang terkenal di Singapura seperti Chili Crab, Laksa Singapura, Hokkien Prawn Mee, Nasi Ayam Hainan, Fried Carrot Cake, Mee Pok, Char Kway Teow, kudapan (seperti Chwee Kueh, Kaya Toast, dan Ah-Balling), dan masih terdapat ragam kuliner Tiongkok lainnya. Budaya India dan Melayu juga turut berperan dalam daftar makanan khas Singapura, antara lain Nasi Biryani, Nasi Lemak, Mi Siam, Rojak, Kari Kepala Ikan, kudapan (seperti Roti Prata, Vadai, Roti Canai, serta minuman seperti Teh Tarik, Cendol, YuanYang, dan Ice Kachang).

Penelitian perusahaan khusus outbound tourism Pear Anderson tahun 2019 menyatakan bahwa wisatawan Indonesia gemar berbelanja ketika sampai di suatu destinasi wisata. Pernyataan ini mendukung hasil penelitian pada Tabel 2. bahwa aktivitas kedua terbanyak yang dilakukan oleh wisatawan Indonesia milenial selama berwisata di Singapura adalah Wisata Belanja. Banyaknya destinasi wisata di Singapura yang memiliki pusat perbelanjaan seperti Orchard Road, Bugis Street, Little India, dan Chinatown, turut menunjang sifat gemar belanja dari para wisatawan. Harga produk asli yang relatif lebih murah dibandingkan ketika berbelanja di Indonesia juga menjadi pullfactor kegiatan wisata belanja bagi wisatawan Indonesia milenial di Singapura.

Aktivitas ketiga yang paling banyak diminati oleh wisatawan Indonesia milenial adalah menikmati budaya lokal dengan persentase sebesar $48.6 \%$ dari total responden.
Walaupun dikenal sebagai negara yang maju dan modern, Singapura tetap mempertahankan warisan budayanya sejak dahulu. Hal ini dapat dibuktikan bahwa terdapat banyak daerah dengan budaya yang kental seperti Chinatown (budaya Tiongkok), Little India (budaya India), dan Bugis Street (budaya Melayu). Saat melakukan wisata kuliner ataupun wisata belanja, wisatawan juga akan menikmati budaya yang ada di sekitarnya.

\section{SIMPULAN \& SARAN \\ Simpulan}

Berdasarkan hasil pembahasan dari penelitian yang dilakukan penulis, dapat simpulan sebagai berikut.

Singapura merupakan destinasi wisata outbound favorit wisatawan milenial asal Indonesia. Terdapat sembilan daya tarik wisata utama yang berada di Singapura, yaitu Marina Bay Singapore, Sentosa Island, Singapore Zoo, Orchard Road, Gardens By the Bay, Singapore river, Bugis Street, Little India, dan Chinatown. Dilihat dari karakteristik sosio-demografis, mayoritas wisatawan milenial mancanegara yang berkunjung ke Singapura berjenis kelamin perempuan, berusia 21 hingga 25 tahun, belum menikah, tingkat pendidikan hingga Sarjana dan berprofesi sebagai pegawai swasta. Ditinjau dari karakteristik perjalanannya, mayoritas wisatawan merupakan wisatawan yang baru datang pertama kali ke Singapura (first timer), berkunjung dalam kurun waktu 3 hingga 7 hari, melakukan perjalanan bersama keluarga, mengatur sendiri pengorganisasian perjalanannya, menggunakan fasilitas internet sebagai sumber informasi selama berada di Singapura dan MRT (Mass Rapid Transit) merupakan moda transportasi yang dipilih untuk melakukan perjalanan wisata.

Hasil penelitian menunjukkan bahwa ada dua pola perjalanan wisatawan Indonesia milenial selama berwisata di Singapura, yakni Pola Perjalanan Base Site (dua destinasi, dan tiga destinasi), dan Pola Perjalanan Chaining Loop. Pada pola perjalanan Base Site Dua Destinasi, destinasi yang dipilih mayoritas wisatawan adalah Marina Bay Singapore sebagai destinasi utama, dan Orchard Road sebagai destinasi kedua atau destinasi terakhir sebelum kembali ke tanah air. Pada pola perjalanan Base Site Tiga Destinasi, destinasi utama pilihan wisatawan Indonesia milenial adalah Sentosa Island, kemudian destinasi 
kedua adalah Gardens By The Bay, dan destinasi terakhir ialah Orchard Road.

Pola perjalanan terakhir adalah Chaining Loop, dimana wisatawan melakukan rute memutar tanpa mengulangi rute yang sama, yaitu mengunjungi Marina Bay Singapore sebagai destinasi utama, kemudian melanjutkan perjalanan menuju Chinatown, Orchard Road, Gardens By The Bay, dan terakhir adalah Sentosa Island. Berdasarkan hasil penelitian dapat disimpulkan bahwa wisatawan Indonesia milenial bergerak menuju destinasi wisata yang sudah terkenal, memiliki banyak pengunjung. Mayoritas wisatawan Indonesia milenial memilih Marina Bay Singapore sebagai destinasi wisata utama, dan memilih Orchard Road sebagai destinasi wisata kunjungan terakhir. Pola perjalanan wisatawan Indonesia milenial di Singapura berfokus pada daya tarik wisata perkotaan yang berada di Wilayah Selatan Negara Singapura.

Dalam beraktivitas, wisatawan milenial lebih banyak melakukan aktivitas wisata khusus dan wisata budaya seperti wisata kuliner, wisata belanja, dan menikmati budaya lokal, daripada aktivitas wisata alam. Pernyataan ini dikuatkan oleh fakta bahwa Singapura merupakan negara yang memiliki lebih banyak daya tarik wisata non-alami seperti Sentosa Island, Marina Bay Singapore, Orchard Road, dan lainnya. Adanya perpaduan budaya dalam sejarah negara Singapura membuahkan hasil berupa daya tarik wisata budaya seperti Chinatown, Bugis Street, dan Little India. Pada daya tarik wisata budaya ini, terdapat beragam kuliner khas masing-masing etnis serta pernak-pernik yang cocok dijadikan sebagai buah tangan saat kembali ke tanah air. Oleh karena itu, aktivitas yang banyak dilakukan wisatawan Indonesia milenial adalah wisata kuliner, wisata belanja, dan menikmati budaya setempat.

\section{Saran}

Penelitian ini merupakan penelitian deskriptif, sehingga tidak dapat menjelaskan hubungan kausatif, namun dapat digunakan sebagai acuan dasar penelitian selanjutnya dan bagi pengembangan segmen pariwisata berorientasi milenial di Indonesia.

Hasil penelitian mengenai pola perjalanan dan aktivitas wisatawan Indonesia milenial di Singapura dapat membantu pemerintah dan/atau pihak-pihak terkait industri pariwisata dalam mengetahui tren berwisata wisatawan Indonesia milenial, khususnya pergerakan mengunjungi destinasi wisata perkotaan.

Saran khusus bagi para pembaca agar tetap menjaga nama baik Negara Indonesia saat melakukan kegiatan wisata di Singapura dan/atau negara-negara lainnya. 


\section{Kepustakaan}

Getzoff, Marc. 2020. Most Technologically Advanced Countries In The World 2020. Majalah Elektronik (e-magazine). Global Finance Magazine. Link: https://www.gfmag.com/global-data/noneconomic-data/best-tech-countries (diakses pada 7 April 2021)

Hidayat, Muhammad Anas. 2018. Daya tarik Wisata Perkotaan Di Singapura. Makalah Penelitian Foreign Case Study. Yogyakarta: Sekolah Tinggi Pariwisata Ambarrukmo.

Leli Kusuma Dewi, Luh Gede. 2020. Pola Perjalanan Dan Pengeluaran Wisatawan Milenial Ke Bali. Jurnal Fakultas Pariwisata Universitas Udayana Vol. 8, No. 1. Jurnal IPTA: Universitas Udayana.

Pearson, Hannah. 2019. Indonesia Outbound Travel Profile. Buku Elektronik (E-book). Malaysia: Pear Anderson Travel Industry Consultancy Firm.

Pratama, Aditya Maulana, I Putu Sudana dan Ni Made Sofia Wijaya. 2020. Analisis Pola Perjalanan dan Aktivitas Wisatawan Milenial Mancanegara yang Berkunjung ke Daya Tarik Wisata di Desa Pecatu, Kabupaten Badung. Jurnal IPTA Vol. 8, No. 1. Denpasar: Universitas Udayana.

Satrya, Dewa Gde. 2018. Berwisata Sebagai Hak Asasi Manusia. Artikel Online Hotel and Tourism Business Universitas Ciputra. Link: https://www.uc.ac.id/htb/berwisatasebagai-hak-asasi-manusia/ (diakses pada 14 Januari 2021)

Suwena, I Ketut dan I Gusti Ngurah Widyatmaja. 2017. Pengetahuan Dasar Ilmu Pariwisata. Denpasar: Pustaka Larasan.

Utami, Fahma Nur dan M. Baiquni. 2019. Pola Pergerakan Spasial Wisatawan yang Berkunjung ke Candi Borobudur. Jurnal Bumi Indonesia. Yogyakarta: Universitas Gajah Mada.

Visit Singapore. 2019. Situs Web Visit Singapore. Link: https://www.visitsingapore.com/id_id/tra vel-guide-tips/getting-around/ (diakses pada 27 Desember 2020). 